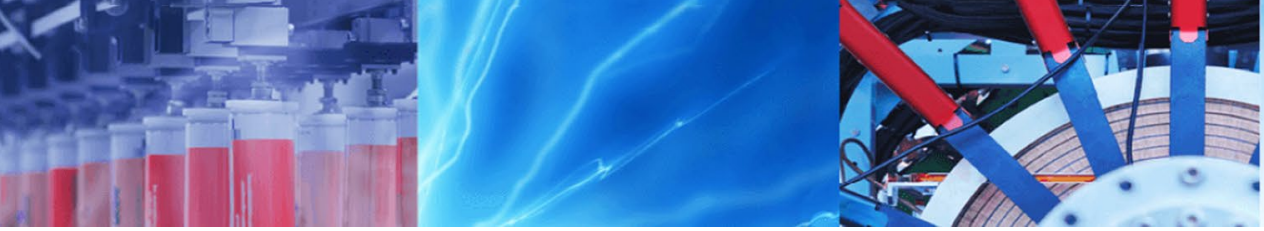

Case Study

\title{
The analysis of freshwater pearl mussel shells using $\mu$-XRF (micro-x-ray fluorescence) and the applicability for environmental reconstruction
}

\author{
J. J. Leppänen ${ }^{1,5}$ (D) T. Saarinen ${ }^{2} \cdot$ T. Jilbert $^{3} \cdot$ P. Oulasvirta ${ }^{4}$
}

Received: 16 October 2020 / Accepted: 17 December 2020 / Published online: 28 December 2020

(C) The Author(s) 2020 OPEN

\begin{abstract}
Freshwater pearl mussel is a highly threatened species, and many populations are currently on the brink of local extinction. For example, in south Finland, only two populations are currently viable. Even though the reasons for the mussels' demise are relatively well known, the long-term impacts of water quality are not completely resolved. Here, $\mu$-XRF analysis and historical records were used to evaluate whether the differences in water chemistry or past environmental changes in three rivers in southern Finland are visible in mussel shell chemistry. The results show that the cracks inside mussel shells, invisible to the naked eye, may greatly affect the elemental composition results. Further, anomalies which could be related to inclusion of detrital matter inside the shells were detected. Manganese (Mn) seems to be related to mussel growth dynamics, especially in the nacreous layer, while high values of iron (Fe) and $\mathrm{Mn}$ are also present at the top sections of the prismatic layer. Line scan analysis revealed high variation between replicates. The $\mu$-XRF method could be used as prescreening method in mussel sclerochemistry studies, but more studies are needed to clarify the ability of FPM shells to reliably record the environmental conditions.
\end{abstract}

Keywords River $\cdot$ Endangered species $\cdot$ Invertebrates $\cdot$ New technique $\cdot$ Pollution

\section{Introduction}

The freshwater pearl mussel, FPM (Margaritifera margaritifera L.), is an endangered bivalve, which has been declining throughout the European part of its range during the past decades [27], and the species is consequently protected within the European Union [10]. The FPM is listed in Annex II of the European Habitats Directive, requiring EU Member States to designate special areas of conservation which contribute to a network of European sites, Natura 2000. The FPM prefers clear and clean waters, where the bottom substrate is clean gravel material and the reproduction success depends on adequate populations of host fish, in Europe, brown trout and Atlantic salmon [27]. The reasons behind the demise of FPM are related to pearl fishing, which is nowadays illegal in European countries, loss of host fish communities (e.g., due to hydropower dams), decline in water quality (eutrophication, pollution) and siltation (drainage of forest and peat lands, channel manipulation, road construction) $[4,14,32]$. The majority of riverine systems in southern Finland have been affected by most of the above-mentioned human interferences, and

Supplementary information The online version contains supplementary material available at (https://doi.org/10.1007/s42452-020-03978 $-3)$.

$\triangle$ J. J. Leppänen, jaakko.leppanen@helsinki.fi | ${ }^{1}$ Environmental Change Research Unit (ECRU), Helsinki Institute of Sustainability Science (HELSUS), Ecosystems and Environment Research Program, Faculty of Biological and Environmental Sciences, University of Helsinki, Helsinki, Finland. ${ }^{2}$ Department of Geography and Geology, University of Turku, Turku, Finland. ${ }^{3}$ Aquatic Biogeochemistry Research Unit, Ecosystems and Environment Research Program, Faculty of Biological and Environmental Sciences, University of Helsinki, Helsinki, Finland. ${ }^{4}$ Alleco LTD, Helsinki, Finland. ${ }^{5}$ Present Address: Uusimaa Centre for Economic Development, Transport and the Environment, Helsinki, Finland. 
thus it is not surprising that healthy FPM populations in southern Finland are very rare. Only two south Finnish FPM populations are viable, whereas five others have not been able to reproduce in recent years or recent decades [32].

Even though the reasons behind FPM decline are relatively well known, the lack of long-term water monitoring data hampers investigations of chronic impacts of water quality deterioration on FPM. Because water monitoring programs rarely exceed the maximum age of FPM (over 100 years; [27], the water quality and the general environmental histories of FPM rivers and watersheds are not well known even in sites with decades of monitoring. Luckily, shells of dead bivalves are known to hold potential to study the environmental conditions to which they were exposed to when the mussels were alive (e.g., $[2,6,30,33$, 36]. This is based on the idea that during the biomineralization of the shell, some chemical impurities of the water are potentially incorporated into the shell. FPM shells consist of three layers. The outmost layer is the organic periostracum, which prevents the dissolution of calcium carbonate. Periostracum is followed by two aragonite zones: prismatic layer below the periostracum and the innermost nacreous layer [30]. Furthermore, growth of the mussels slows down during cold months and this phenomenon is visible in the shells as winter lines, analogous to tree rings [30,37]. Therefore, there is potential to assess historical changes in environment by studying the mussel shell chemistry from dated shell cross sections (sclerochronology). For example, $\mathrm{d} 180$ values of mussel shells have been noted to reflect stream water isotope composition [33,36], and $\mathrm{d} 13 \mathrm{C}$ values in shells were shown to mirror metabolic activity [12]. The elemental chemistry of freshwater bivalve shells, however, is more challenging to interpret [15].

In this study, the spatial variation of elemental composition was assessed in the cross sections of nine mussels shells retrieved from three rivers in southern Finland. All studied rivers are located in rural catchments with agricultural activity. In general, human activities have induced increased inputs of many trace elements into the agroecosystems due to repeated use of industrial chemicals and fertilizers [25]. In many cases, this has resulted in ecological changes in aquatic systems, such as eutrophication [22]. However, the studied rivers exhibit differences in environmental conditions and each river system has experienced varying histories of anthropogenic influence. The primary goals of the study aimed to determine the distribution of elements in different shell layers, changes during time and differences among specimens and rivers. Main hypothesis was that the differences in water chemistry between rivers are reflected to the elemental composition of the shells. Our secondary hypothesis was that the known historical changes in river environment are recorded in the elemental chemistry of mussel shells.
In order to study the variation of the elements in the shell cross sections, elemental maps were produced using micro-X-ray fluorescence analysis ( $\mu$-XRF analysis; e.g., [23] and a line scan analysis was applied across the outer shell layer. This is a preliminary study in which $\mu$-XRF methods are used to study FPM for the first time. $\mu$-XRF method is fast and nondestructive analysis method allowing extremely high density of sampling points in small area. The $\mu$-XRF analysis has been used in plethora of studies, including geosciences, art history, archeology, environmental and biological sciences and for industrial purposes [21]. In addition, the Mutvei staining/dating method [37] was used in order to assess the age-at-shell length.

\section{Methods}

\subsection{Study sites}

The characteristics of the studied rivers are presented in Table 1. The River Mustionjoki is one of the largest river systems in south Finland (channel width $\sim 40 \mathrm{~m}$, depth $\sim 3 \mathrm{~m}$ ), whereas the River Pinsiön-Matalusjoki and the River Ruonanjoki are very small rivers (channel width $\sim 5 \mathrm{~m}$, depth $\sim 0.5 \mathrm{~m})$. The River Mustionjoki begins at the Lake Lohjanjärvi $\left(\sim 88 \mathrm{~km}^{2}\right)$, and the outlet is located at the Pohjanpitäjänlahti Bay, the Gulf of Finland (Fig. 1). Lohjanjärvi experienced serious water quality deterioration during the 1960s due to the release of untreated municipal and industrial (forest industry) wastewaters. Further, wastewaters of the metal industry have affected the water quality in the River Mustionjoki [29]. According to [31] the River Mustionjoki experienced high mineral oil pollution during 1976 (maximum concentration $74 \mathrm{mg} / \mathrm{L}$ ) and cyanide pollution in 1977-1978 (maximum concentration $690 \mu \mathrm{g} / \mathrm{L}$ ). The impact of the metal industry is visible in the sediments of the Pohjanpitäjänlahti Bay showing distinct Fe peak in the late 1970's [20]. The source of the River Pinsiön-Matalusjoki are the springs at Pinsiönharju esker, and the river flows through peatland forests and cultivated fields. The most interesting historical change is the drying of two lakes, Lake Pikku-Matalus $\left(\sim 0.03 \mathrm{~km}^{2}\right)$ and Lake Iso Matalusjärvi $\left(\sim 0.14 \mathrm{~km}^{2}\right)$, located upstream from the FPM site, in 1955 [19]. Lake dryings could have affected the river water quality due to increased erosion [7]. The River Ruonanjoki starts at Lake Karhejärvi $\left(\sim 3 \mathrm{~km}^{2}\right)$ and flows southward through forests and cultivated fields into the Lake Laavajärvi $\left(\sim 1.9 \mathrm{~km}^{2}\right)$. The water chemistry of the lakes has not experienced significant changes since $\sim 1970^{\prime}$ [31] and corresponds with that of the River Ruonanjoki. Moreover, according to old maps, the river catchment has remained unchanged during the past decades; the direct human impact is negligible in the river valley. 
Table 1 River characteristics

\begin{tabular}{|c|c|c|c|}
\hline River name & River Mustionjoki & River Pinsiön-Matalusjoki & River Ruonanjoki \\
\hline Latitude (WGS 84) & 60.0811 & 62.5222 & 61.67147 \\
\hline Longitude (WGS 84) & 23.66208 & 23.32786 & 23.42823 \\
\hline Length (km) & 26 & 10.5 & 14.5 \\
\hline Ammonium. as N NH4-N ( $\mu \mathrm{g} / \mathrm{L})$ & 64.1 & 20.6 & 15.2 \\
\hline $\operatorname{COD}(\mathrm{mg} / \mathrm{L})$ & 8.3 & 9.8 & 14.1 \\
\hline Solids (mg/L) & 3.5 & 5.5 & 6.3 \\
\hline $\operatorname{TotP}(\mu \mathrm{g} / \mathrm{L})$ & 28.7 & 36.5 & 29.5 \\
\hline TotN $(\mu \mathrm{g} / \mathrm{L})$ & 695 & 922 & 670 \\
\hline Coliform count (ind/100 ml) & 165 & 297 & 81 \\
\hline Temperature ${ }^{\circ} \mathrm{C}$ & 17.3 & 11.6 & 13.6 \\
\hline $\mathrm{pH}$ & 7.4 & 6.7 & 6.8 \\
\hline $\mathrm{Fe}(\mu \mathrm{g} / \mathrm{L})$ & 264 & 1275 & 636 \\
\hline Turbidity (FNU) & 4.1 & 5.4 & 3.4 \\
\hline $\mathrm{EC}(\mathrm{mS} / \mathrm{m})$ & 15.3 & 9.8 & 5.2 \\
\hline Color (mg/L Pt) & 30 & 117 & 86 \\
\hline Catchment area (km2) & 2045.8 & 47.9 & 129.4 \\
\hline Catchment land use & Agriculture and forests & Agriculture and forests & Agriculture and forests \\
\hline Catchment soil class & Silt and clay deposits & Silt and peatland & Silt and clay deposits \\
\hline Catchment rock class & $\begin{array}{l}\text { Microcline granite; quartz feldspar } \\
\text { paragneiss (tot. 34\%) }\end{array}$ & Granodiorite (54\%) & Porphyritic granite (56\%) \\
\hline
\end{tabular}

Surface water data from June to September, 1996-2019. The sample number for each parameter varied between 6 and 61 . Catchment characteristics are the types which occur in the vicinity of river channel, whereas the percentage inside brackets (with rock type class only) is the proportion of that type within the catchment (OIVA Database 2020)
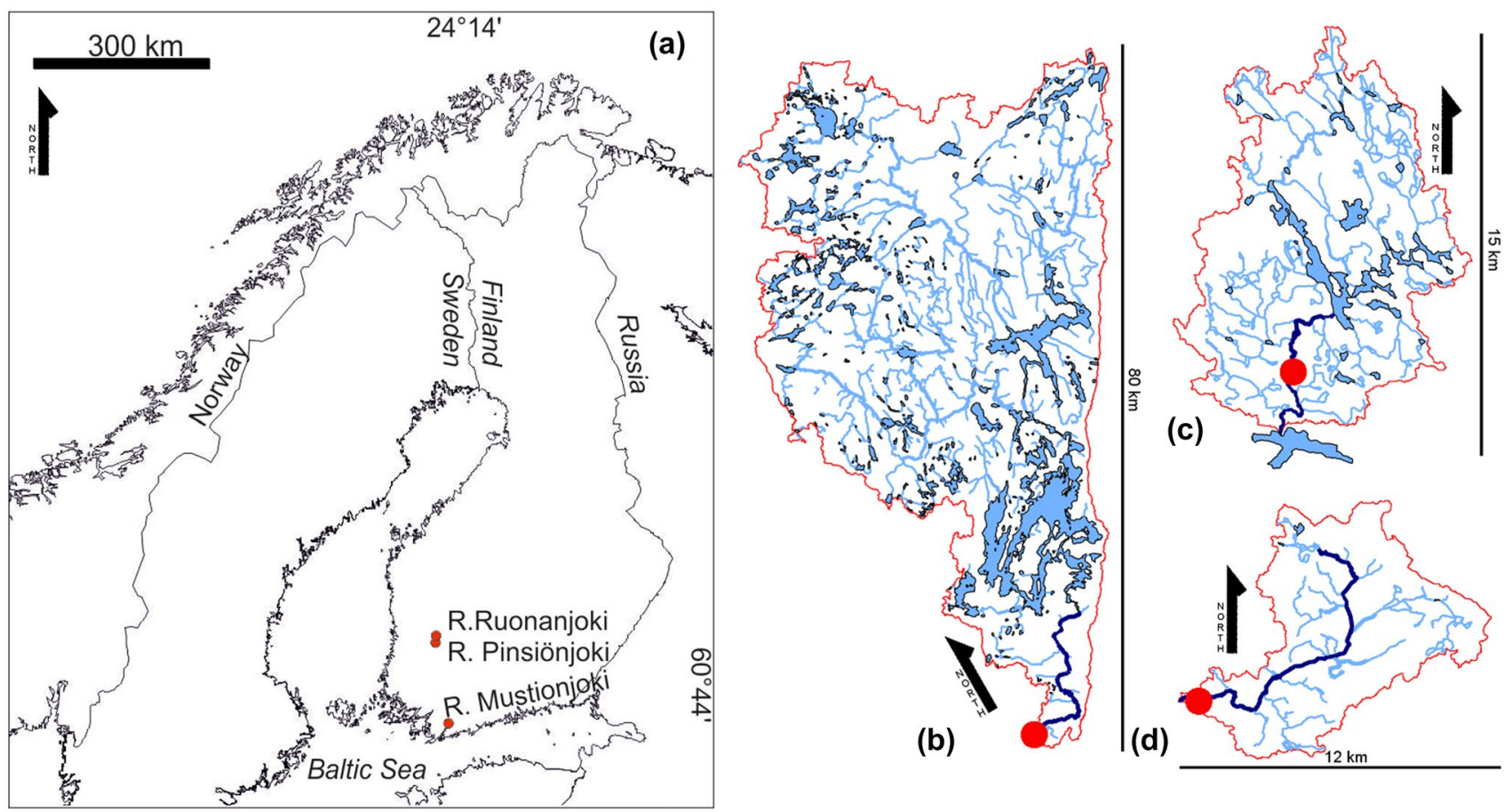

Fig. 1 Map of sampling locations a. Catchment map of River Mustionjoki b, River Ruonanjoki c and River Pinsiön-Matalusjoki d. The river channel is denoted in darker blue, and red dots represent the approximate site of sample retrieval 


\subsection{Mussel samples}

Shells of deceased $M$. margaritifera were collected by a diver from each river in the summer of 2019. The shells were examined and their dimensions were logged. Subsequently, three shells (replicates) from each river were selected for analysis. The selection was based on the condition of shells: well-preserved periostracum and inner shell surface with typical aragonite luster as in freshly deceased specimens were selected. Shells were stored in dark cold room prior to analysis. Cross-section samples were prepared at the laboratory of the Department of Geology, Helsinki University. In short, the mussel shells were cut from the umbo to the ventral margin (height axis) using a diamond saw in perpendicular manner to winter lines. The cut surface was polished and mounted to a glass slide with epoxy. The method for cross-section preparation is published in detail in Haag and Commens-Carson [17].

\section{$2.3 \mu-X R F$ analysis}

In order to study the spatial variation of elements in mussel cross sections, distribution maps of elements (2D maps) were produced by a Bruker M4 Tornado micro-X-ray fluorescence ( $\mu$-XRF) spectrometer with two silicon drift detectors and $\mathrm{Rh}$ anode. The spot size of capillary optics $\mathrm{X}$-ray beam was c. $20 \mu \mathrm{m}$. After calibration of spectrometers with a Zr standard, the mussel samples were fixed on measurement stage and pressure of the chamber was dropped down to 20 mbar. High voltage of $50 \mathrm{kV}$ and $600 \mu \mathrm{A}$ current were used for samples. The size of the analyzed area was $68.6 \mathrm{~mm} \times 84.8 \mathrm{~mm}$ with a pixel distance of $30 \mu \mathrm{m}$. The beaming time was $10 \mathrm{~ms} /$ pixel. The total number of pixels was about $6.47 \mathrm{M}$ and measuring time was $15 \mathrm{~h}$. A hypermap with spectra of every single pixels was stored in a computer for later analysis. Distribution maps of elements were based on investigation of the total spectrum. Most distinct energy peaks of Ka and La were used to identify elements from the samples. 2D maps were investigated with different filters (e.g., enhancement of color intensity) in order to detect the variation in low value sites. To assess the average elemental composition of prismatic layer and temporal variation of elements, line scan analysis was conducted from dorsal toward ventral direction across the prismatic layer from each shell (i.e., line scan route intersecting the winter lines) (Fig. 2).

\subsection{Dating}

After the $\mu$-XRF analysis, the samples were stained using Mutvei's solution with Brilliant Blue staining [37] and winter lines (Fig. 2) were counted using microscope photography in order to establish a crude chronology. The eroded

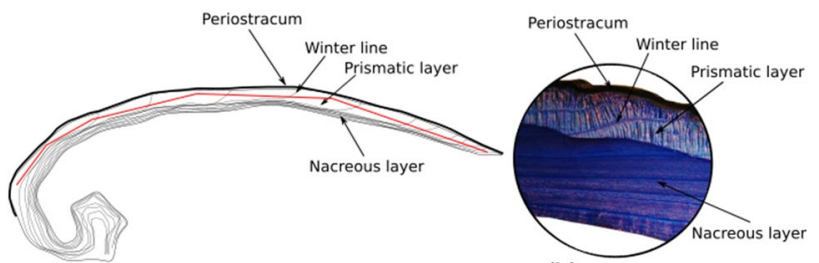

(a)

(b)

Fig. 2 Mussel thin section sample. Most important layers (periostracum, prismatic layer and nacreous layer and annual winter lines are marked in the drawing $\mathbf{a}$ and in the detail photograph of stained mussel cross-section sample b. Red line denotes the line scan analysis route. Left side of the shell sample $\mathbf{a}$ is dorsal region (long ago formed shell) and right side is ventral region (most recently formed shell)

sections (near umbo) were not included in the age analysis, and the replicates were not cross-dated.

\subsection{Statistical methods}

Kruskal-Wallis test was used to assess the elemental variation between replicates. Kruskal-Wallis test was conducted for each element using PAST statistics with the dataset obtained from the line analysis. The nonparametric test was chosen due to nonnormality of the data.

\section{Results}

Mussel shells varied in size, abundance of periphyton and precipitate crust and umbo corrosion damage. In general, the mussels were in similar condition regarding the overall strength, hinge ligament and periostracum. A thin $(\sim 0.5 \mathrm{~mm})$ orange/brown crust of metallic character was detected in two Ruonanjoki shells (R1 and R3) and in one Pinsiön-Matalusjoki (M3) shell. The crust flaked away during the sample preparation. All River Mustionjoki shells were covered with aquatic moss. The number of counted winter lines varied from 46 to 68 , and the length of the mussels varied between 106 and $140 \mathrm{~cm}$ (Table 2). River Ruonanjoki shells were clearly thinner than the shells from other studied rivers.

\section{1 $\mu$-XRF analysis}

The composite $\mu$-XRF spectrum of the shell samples exhibited distinct peaks for manganese $(\mathrm{Mn})$, iron (Fe), aluminum ( $\mathrm{Al})$, strontium $(\mathrm{Sr})$, zirconium $(\mathrm{Zr})$, sulfur $(\mathrm{S})$ and calcium ( $\mathrm{Ca}$ ). As expected, the Ka intensity values of $\mathrm{Ca}$ in the undamaged sections of mussel shells are relatively homogeneous (Figs. 3, 4). Other elements are present in low concentration in the high-calcium layers (nacreous layer and prismatic layer), whereas the mussel 
Table 2 General characteristics of mussel samples

\begin{tabular}{llll}
\hline Sample & Length $(\mathrm{mm})$ & Height $(\mathrm{mm})$ & \# winter lines \\
\hline P1 & 111 & 55 & 64 \\
P2 & 124 & 61 & 65 \\
P3 & 116 & 56 & 65 \\
R1 & 136 & 71 & 56 \\
R2 & 140 & 70 & 52 \\
R3 & 125 & 62 & 46 \\
M1 & 111 & 54 & 60 \\
M2 & 106 & 50 & 55 \\
M3 & 107 & 51 & 68 \\
\hline
\end{tabular}

Samples are denoted according to the river names (P1-3 stands for River Pinsiön-Matalusjoki samples, R1-3 for River Ruonanjoki samples and M1-3 for River Mustionjoki samples)

periostracum contains elevated values of different elements ( $\mathrm{Al}, \mathrm{Fe}, \mathrm{Mn}, \mathrm{S})$. The majority of elements in the periostracum show no distinct differences in values levels between samples, whereas Fe shows slightly lower values in $\mathrm{P} 1$ and $\mathrm{P} 3$ and $\mathrm{Mn}$ shows lower values in $\mathrm{R} 1$, $\mathrm{P} 3, \mathrm{M} 2$ and $\mathrm{M} 1$. Sr exhibited low values in periostracum but higher values in nacreous layer and in section near the umbo, whereas $\mathrm{Zr}$ did not exhibit any visible variation in mussel shells. Further, it was clear that Fe and $\mathrm{Mn}$ show higher values in damaged sections and also a varying degree of apparent 'leaching' into the prismatic layer from the periostracum (Fig. 3). Mn exhibited elevated values in nacreous layer and corresponded with

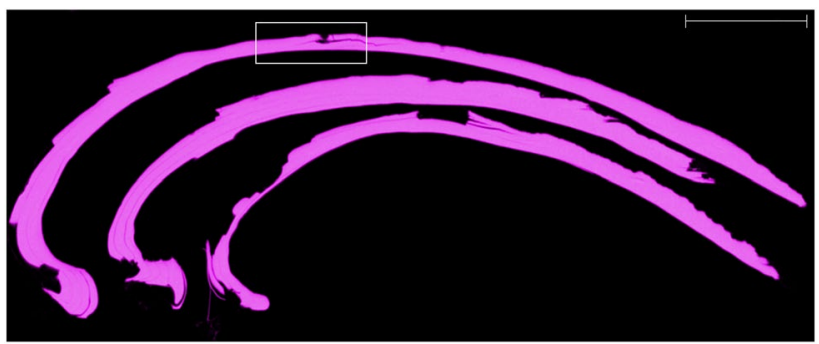

Fig. 4 Enhanced 2D maps for calcium values for samples R1 (top), $\mathrm{P} 1$ and M2. The white rectangle shows the site in Fig. 3. The length of the white bar at top right corner is $10 \mathrm{~mm}$

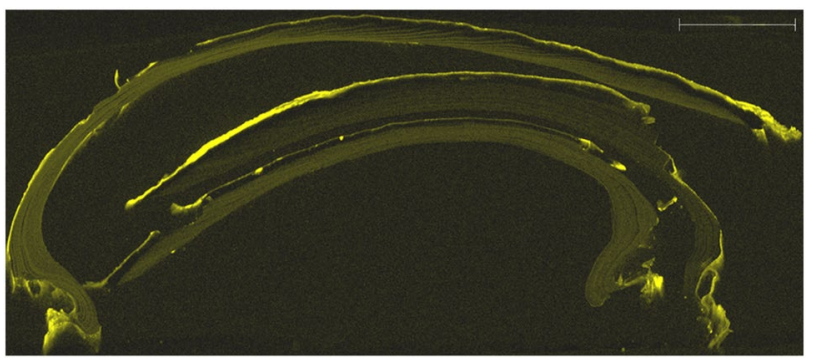

Fig. 5 Enhanced no-filter 2D maps for manganese values for samples R2, M3 and P3. The length of the white bar at top right corner is $10 \mathrm{~mm}$

growth sections which is visible as "Mn stripes" (Fig. 5). Moreover, the Ca $\mu$-XRF map clearly shows multiple crack lines which were invisible for naked eye (Figs. 3, 4). Full elemental maps based on deconvoluted counts with
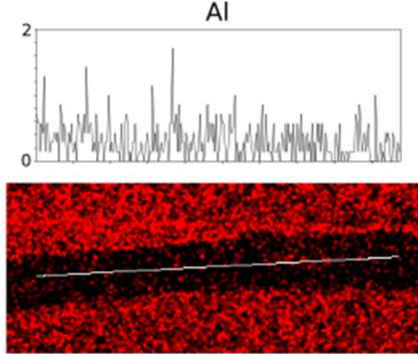

$\mathrm{Mn}$
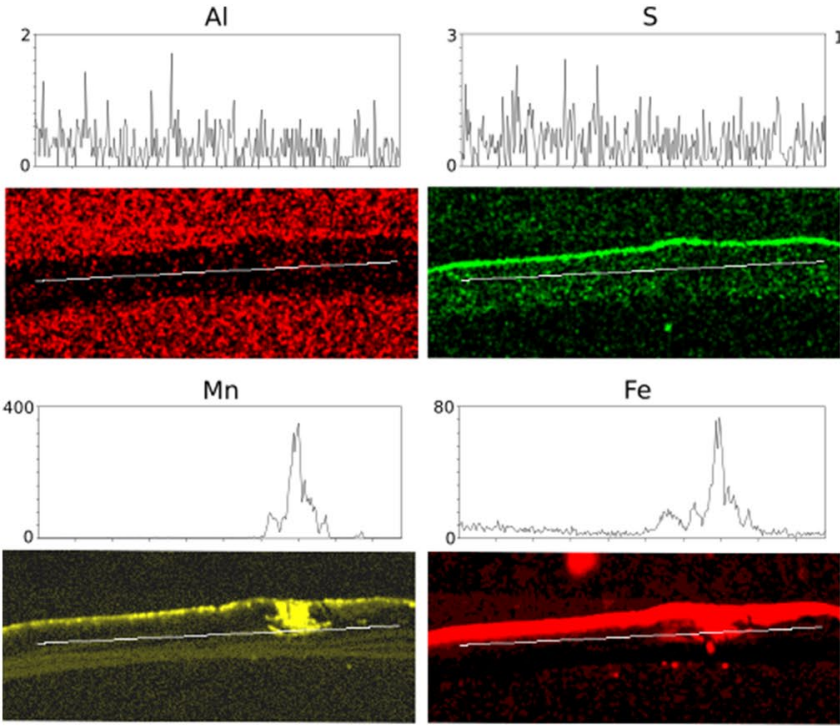

$\mathrm{Fe}$
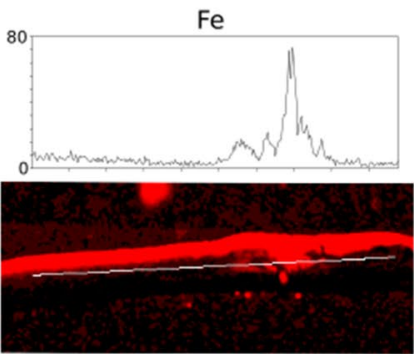

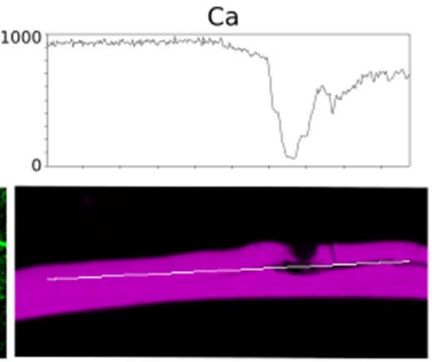

$\mathrm{Sr}$
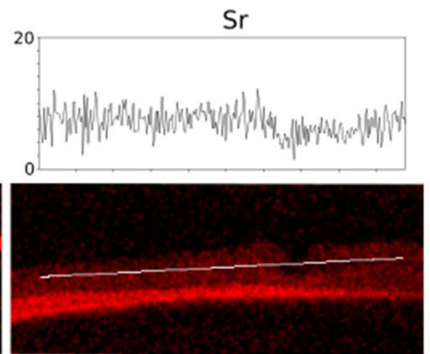

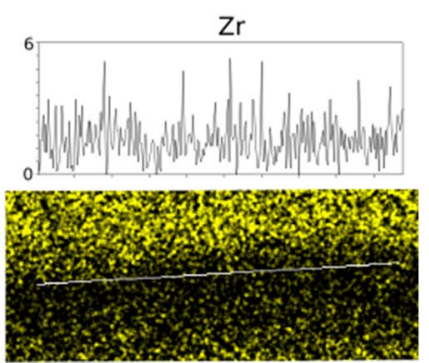

Fig. 3 Selected details from enhanced 2D maps with corresponding line scan analysis results (sample R1; here showing years 1966-1970). The Ca map for the shell R1 is shown in Fig. 4

and all elemental maps in Online Resource 2-7. Higher color intensity corresponds to higher $\mathrm{K}$ alpha -value (i.e., higher elemental concentration) 
five-point average element filter are presented as supplementary material (Online Resource 2-7).

\subsection{Line analysis}

The average shell chemistry in FPM prismatic layer was calculated using the line scan analysis results (Online Resource 8). When all elemental variation is considered, $\mathrm{Fe}, \mathrm{Mn}$ and $\mathrm{Ca}$ stand out for high variation between the replicates and some less clear differences between rivers. Our hypothesis that elemental concentrations in mussel shells can be attributed to the river water chemistry was thus not supported. Fe and $\mathrm{Mn}$ are also characterized by higher standard deviation when compared to other elements (Online Resource 8). According to the Kruskal-Wallis test, nearly all elements exhibit differing values among replicates. Only Al and S values in River Mustionjoki replicates were flagged as not significantly different (KW $1.07 p=0.43$ for Al; KW $0.1 p=0.37$ for S). The differences between replicates are clearly shown in line scan analysis curves. (Online Resource 9). In all shells except R2, there were shell damages which are visible in line scan analysis as low Ca values accompanied by higher values of, for example, Fe and Mn (Fig. 3; Online Resource 9). In River Pinsiön-Matalusjoki samples, the elevated $\mathrm{Zr}$ and $\mathrm{Sr}$ values occur in 1950s. However, peaks and troughs in the elemental profiles can rarely be matched between replicate line scan tracks. Moreover, in P3, M3 and R2, the Ca values show low values in multiple sections despite the lack of visible cracks in shell. Line scan analysis tracks are denoted in Online Resource 1. Even though our dating is only approximate due to lack of intra-annual microgrowth pattern analysis and replicate cross-dating (Schöne et al. 2007), the line scan analysis shows that our hypotheses regarding elevated Fe in River Mustionjoki mussels in 1970s were not supported.

\section{Discussion}

The similar condition of mussel shells suggests that the mussels had died at approximately same time [24]. The age-length relationship was in good agreement with Swedish results [9], and interestingly, the three largest mussels were among the four youngest individuals suggesting fast growth rate in River Ruonanjoki. Temperature has been detected to be positively correlated with FPM growth speed, but the local hydrochemistry may have significant effect on growth (e.g., [1, 9, 28]. Because River Ruonanjoki is considerably colder $\left(13.6^{\circ} \mathrm{C}\right)$ when compared with River Mustionjoki $\left(17.3^{\circ} \mathrm{C}\right)$, the temperature does not explain fast growth in River Ruonanjoki. Eutrophication [1] and elevated ammonium concentration are noted to be harmful to FPM [5], and the beneficial conditions at River Ruonanjoki (lowest ammonium, N, bacterial, EC and turbidity values between the study rivers) may explain the higher growth speed despite colder water.

The general elemental composition and the result that Fe was responsible for high elemental variation among our samples agrees with Bolotov et al. [3], but due to methodological differences (ICP-MS whole shell in [3] some light elements, e.g., $\mathrm{Na}, \mathrm{Mg}, \mathrm{P}$ are not detectable in our results. However, the observations regarding the elemental distribution in thin sections are in accordance with earlier mussel studies. For example, the high concentration of $\mathrm{S}$ [40] and $\mathrm{Mn}$ and Fe in the periostracum layer is very wellknown phenomenon [39]. Further, $\mathrm{Mn}$ has been noted to show higher values in annual growth increments in contrast to winter lines [26], which is thus in agreement with results. The elevated values of Fe below the periostracum have been reported before [41] but the reason for this is unclear.

The low Ca counts corresponding with elevated $\mathrm{Mn}, \mathrm{Fe}$ and $S$ could result from inclusion of detrital matter into the shell at points of shell damage (many such imperfections are visible in Ca maps, e.g., Fig. 4). The uneven surface thus created also introduces analytical artifacts in the XRF data [8]. It is likely that both of these factors contribute to extreme values where the line scans cross points of shell damage (Online Resource 9). Zr and Sr exhibited peaks in River Pinsiön-Matalusjoki samples which dated to 1950 s. High concentrations of $\mathrm{Zr}$ in stream water are usually related to the occurrence peat lands, whereas $\mathrm{Sr}$ is easily mobilized by weathering and is strongly incorporated in clay minerals and fixed by organic matter [35]. As such, both elements may reflect the magnitude of erosion and these peaks could be related to drying of the upstream lakes. However, similar variation in shells retrieved from other rivers with no known cases of such changes in upstream suggests that other factors contribute to the $\mathrm{Sr}$ and $\mathrm{Zr}$ variation in mussel shells. Further, high $\mathrm{Sr}$ and $\mathrm{Zr}$ were, in many cases, occurring simultaneously with low Ca values; thus, the $\mathrm{Sr}$ and $\mathrm{Zr}$ peaks may be related to shell damage.

Despite the fact that average values for many elements are relatively similar among replicates, the high variation between prismatic layer line scan results hampers the applicability of FPM as chronological recorders of environmental histories when $\mu$-XRF is used. Thus, distinct trends in shell chemistry which could have been linked to different conditions or environmental histories are not visible in the samples. For example, the results do not show any elemental enrichment dating to agricultural boom of late 1940s [22], which could be related to the extensive application of industrial fertilizers (e.g., [25]. The reason for poor correspondence between water 
chemistry and shell chemistry could be related to physiological controls $[11,12,18]$, because the biomineralization of the shell is complicated process and regulated by many physiological and biochemical activities [42].

The observations with interesting potential for shell chemistry studies relate to the thin crusts of Fe and $\mathrm{Mn}$ on the periostracum (Fig. 3). These were observed in two out of three River Ruonanjoki replicates and one out of three Pinsiönjoki-Matalusjoki replicates. The variable occurrence and thickness of these crusts suggests that the chemical milieu of the (micro-)habitats in which the FPM grow may impact on the periostracum chemistry. Most likely, the reason for such phenomenon is related to the quality of the river bed. The river bed sections with high abundance of silt exhibit low redox potential in the interstitial subsequently mobilizing Fe and $\mathrm{Mn}$ followed by re-precipitation at the interface of oxygenated open water [13].

Various sclerochronology -methods have been used for decades in efforts to study the past environmental changes using skeletal parts of biota (e.g., corals, mollusks, fish otoliths) as historical records [15]. Naiad shells have also been used in many studies [28] but there are still challenges in schlerochemical research [43]. In our study, the variation in the elemental concentrations in samples was very high, which hampers the possibilities to track environmental histories of rivers using FPM shell chemistry. The phenomenon of contrasting trends between replicates (e.g., [12] and low correspondence between water and shell concentrations [11] has been reported earlier in mussel shell research. There are also cases where mussel soft tissues have been analyzed for pollutants and the variation between organs and replicates has been high (e.g., $[16,24,34]$ highlighting the difficulties in mussel pollution research where mussels are used as pollution loggers. Further, new challenges, such as inclusion of detrital material and leaching of metals which may disturb any type of point analysis with FPM, were found. However, such phenomena are clearly visible in $\mu$-XRF 2D maps; thus, the method can be used as prescreening method prior to any point analysis. Another problem which is more difficult to tackle is that, as shown in high variation between replicates, (micro-)habitat environmental characteristics or physiological differences affect the shell chemistry. We conclude that to further develop mussel shell proxies, more field studies with larger sample sizes and precise dating are needed. Further, the actual ability of shells to record water chemistry changes could be tested in controlled environment in laboratory settings. However, because the current status of FPM is highly threatened, laboratory assays should be conducted either with individuals from non-threatened FPM populations or with different species.
Acknowledgements $J \mathrm{~J}$ is supported by Finnish Cultural Foundation and Tuuliainen Foundation.

Authors' contributions All authors contributed to the study conception and design. Material collection was performed by PO. $\mu$-XRF analysis was performed by TS. data analysis was performed by JL, TS and TJ. The first draft of the manuscript was written by JL, and all authors commented on previous versions of the manuscript. All authors read and approved the final manuscript.

Funding JJL was supported by Finnish Cultural Foundation and Tuuliainen Foundation.

\section{Compliance with ethical standards}

Conflict of interest The authors declare that they have no conflict of interest.

Open Access This article is licensed under a Creative Commons Attribution 4.0 International License, which permits use, sharing, adaptation, distribution and reproduction in any medium or format, as long as you give appropriate credit to the original author(s) and the source, provide a link to the Creative Commons licence, and indicate if changes were made. The images or other third party material in this article are included in the article's Creative Commons licence, unless indicated otherwise in a credit line to the material. If material is not included in the article's Creative Commons licence and your intended use is not permitted by statutory regulation or exceeds the permitted use, you will need to obtain permission directly from the copyright holder. To view a copy of this licence, visit http://creativecommons .org/licenses/by/4.0/.

\section{References}

1. Bauer $G$ (1992) Variation in the life span and size of the freshwater pearl mussel. J Anim Ecol 61:425-436

2. Binkowski ŁJ, Błaszczyk M, Przystupińska A, Ożgo M, Massanyi $P$ (2019) Metal concentrations in archaeological and contemporary mussel shells (Unionidae): reconstruction of past environmental conditions and the present state. Chemosphere 228:756-761

3. Bolotov IN, Pokrovsky OS, Auda Y, Bespalaya JV, Vihrev IV, Gofarov MY et al (2015) Trace element composition of freshwater pearl mussels Margaritifera spp. across Eurasia: testing the effect of species and geographic location. Chem Geol 402:125-139

4. Boon PJ, Cooksley SL, Geist J, Killeen IJ, Moorkens EA, Sime I (2019) Developing a standard approach for monitoring freshwater pearl mussel (Margaritifera margaritifera) populations in European rivers. Aquat Conserv 29:1365-1379

5. Buddensiek V (1995) The culture of juvenile freshwater pearl mussels Margaritifera margaritifera L. in cages: a contribution to conservation programmes and the knowledge of habitat requirements. Biol Conserv 74:33-40

6. Carell B, Forberg S, Grundelius E, Henrikson L, Johnels A, Lindh $U$ et al (1987) Can mussel shells reveal environmental history? Ambio 16:2-10

7. Carmignani JR, Roy AH (2017) Ecological impacts of winter water level drawdowns on lake littoral zones: a review. Aquat Sci 79:803-824 
8. De Winter NJ, Claeys P (2016) Micro X-ray fluorescence (IXRF) line scanning on Cretaceousrudist bivalves: A new method for reproducible trace element profiles in bivalve calcite. Sedimentology. https://doi.org/10.1111/sed.12299

9. Dunca E, Söderberg H, Norrgrann O (2011) Shell growth and age determination in the freshwater pearl mussel Margaritifera margaritifera in Sweden: natural versus limed streams. Ferrentia 64:48-58

10. EEC (1992) Council Directive 92/43/EEC on May 1992 on the conservation of natural habitats and of wild fauna and flora

11. Freitas PS, Clarke LJ, Kennedy H, Richardson CA (2016) Manganese in the shell of the bivalve Mytilus edulis: seawater Mn or physiological control? Geochim Cosmochim Acta 194:266-278

12. Geist J, Auerswald K, Boom A (2005) Stable carbon isotopes in freshwater mussel shells: environmental record or marker for metabolic activity? Geochim Cosmochim Acta 69:3545-3554

13. Geist J, Auerswald K (2007) Physicochemical stream bed characteristics and recruitment of the freshwater pearl mussel (Margaritifera margaritifera). Freshw Biol 52:2299-2316

14. Geist J (2010) Strategies for the conservation of endangered freshwater pearl mussels (Margaritifera margaritifera L.): a synthesis of conservation genetics and ecology. Hydrobiologia 644:69-88

15. Gillikin DP, Wanamaker AD, Andrus CFT (2019) Chemical sclerochronology. Chem Geol 526:1-6

16. Gundacker C (2000) Comparison of heavy metal bioaccumulation in freshwater Mollusks of urban river habitats in Vienna. Env Poll 110:61-71

17. Haag WR, Commens-Carson AM (2008) Testing the assumption of annual shell ring deposition in freshwater mussels. Can J Fish Aquat Sci 65:493-508

18. Hattan SJ, Laue TM, Chasteen ND (2001) Purification and characterization of a novel calcium-binding protein from the extrapallial fluid of the mollusc, Mytilus edulis. J Biol Chem 276:4461-4468

19. Ingelin S (2000) Pinsiön-Matalusjoen alueen suojavyöhykkeiden yleissuunnitelma. Pirkanmaan ympäristökeskuksen monistesarja 5. Pirkanmaan Ympäristökeskus, Tampere

20. Jilbert T, Asmala E, Schröder C, Tiihonen R, Myllykangas J-P, Virtasalo JJ et al (2018) Impacts of flocculation on the distribution and diagenesis of iron in boreal estuarine sediments. Biogeosciences 15:1243-1271

21. Janssens KHA, Adams FCV, Rindby A (2000) Microscopic x-ray fluorescence analysis. Wiley, Chichester

22. KeatleyBennettMacDonaldTaranuGregory BEEMGKZEEI (2011) Land-use legacies are important determinants of lake eutrophication in the Anthropocene. PLoS ONE 6(1):e15913

23. Kurunczi S, Török S, Chevallier P (2001) A micro-XRF study of the element distribution on the growth front of mussel shell (species of Unio Crassus Retzius). Mikrochim Acta 137:41-48

24. Leppänen JJ, Leinikki J, Väisänen A (2020) NiSO4 spill inflicts varying mortality between four freshwater mussel species (including protected Unio crassus Philipsson, 1788) in a western Finnish river. Environ Pollut 256:113402

25. He ZL, Yang XE, Stofella PJ (2005) Trace elements in agroecosystems and impacts on the environment. J Trace Elem Med Bio 2-3:125-140

26. Lindh U, Mutvei $H$, Sunder T, Westermark T (1988) Environmental history told by mussel shells. Nucl Instrum Methods Phys Res B 30:388-392

27. Moorkens E, Cordeiro J, Seddon MB, von Proschwitz T, Woolnough D (2018) Margaritifera margaritifera (errata version published in 2018). The IUCN red list of threatened species 2018: e.T12799A128686456
28. Mutvei $\mathrm{H}$, Westermark T (2001) How environmental information can be obtained from Naiad shells. In: Bauer G, Wächtler K (eds) Ecology and evolution of the freshwater mussels unionoida. Ecological studies, Springer, Berlin

29. National Board of Waters (1980) Pohjanpitäjänlahden ja sen edustan vesiensuojelusuunnitelma. Publications of the national board of waters 31. Helsinki

30. Nyström J, Lindh U, Dunca E, Mutvei H (1995) A study of M. margaritifera shells from the River Pauliströmsån, S Sweden. Nucl Instrum Methods Phys Res B 104:612-618

31. OIVA Database (2020) Finnish environmental institute open data. internet page. http://www.avoindata.fi. Accessed 20 April 2020

32. Oulasvirta P, Leinikki J, Syväranta J (2017) Freshwater pearl mussel in Finland-current status and future prospects. Biol Bull 44:81-91

33. Pfister L, Thielen F, Deloule E, Valle N, Lenzen E, Grave $C$ et al (2018) Freshwater pearl mussels as a stream water stable isotope recorder. Ecohydrology 11:e2007

34. Rzymski P, Niedzielski P, Klimaszyk P, Poniedzialek B (2014) Bioaccumulation of selected metals in bivalves (Unionidae) and Phragmites australis inhabiting a municipal water reservoir. Environ Monit Assess 186:3199-3212

35. Salminen R (2005) Geochemical atlas of Europe. GTK and FOREGS. (electronic version). ISBN 951-690-913-2

36. Schöne BR, Meret AE, Baier SM, Fiebig J, Esper J, McDonnell $J$ et al (2020) Freshwater pearl mussels from northern Sweden serve as long-term, high-resolution stream water isotope recorders. Hydrol Earth Syst Sc. https://doi.org/10.5194/ hess-2019-337

37. Schöne BR, Dunca E, Fiebig J, Pfeiffer M (2005) Mutvei's solution: An ideal agent for resolving microgrowth structures of biogenic carbonates. Palaeogeogr Palaeoclimatol Palaeoecol 228:149-166

38. Schöne BR, Rodland DL, Surge DM, Fiebig J, Gillikin DP, Baier SM, Goewert A (2006) Comment on "Stable carbon isotopes in freshwater mussel shells: Environmental record or marker for metabolic activity?" Geochim Cosmochim Acta 70:2658-2661

39. Swinehart JH, Smith KW (1979) Iron and manganese deposition in the periostraca of several bivalve mollusks. Biol Bull 156:369-381

40. Tamenori Y, Yoshimura T (2018) Sulfur speciation in growth layers of shell cross section of the long-lived bivalve Margaritifera laevis using synchrotron spectromicroscopy analysis. Geochim Cosmochim Acta 237:357-369

41. Thorn K, Cerrato RM, Riviers ML (1995) Elemental distribution in marine bivalve shells as measured by synchrotron $\mathrm{X}$-ray fluorescence. Biol Bull 188:57-67

42. Zeng LG, Wang JH, Li YJ, Sheng JQ, Gu Q, Hong YJ (2012) Molecular characteristics and expression of calmodulin CDNA from the freshwater pearl mussel, Hyriopsis sclegelii. Genet Mol Res 11:42-52

43. Zuykov M, Schindler M (2019) Sclerochronology-based geochemical studies of bivalve shells: potential vs reality. Est J Earth Sci 68:37-44

Publisher's Note Springer Nature remains neutral with regard to jurisdictional claims in published maps and institutional affiliations. 